\title{
Implicating Mental Models, Local Interpretation, and Analogy of Facebook Comments upon the News of Paris Attack 11/13
}

\author{
Lisetyo Ariyanti \\ English Literature \\ Universitas Negeri Surabaya \\ Surabaya, Indonesia \\ lisetyoariyanti@unesa.ac.id
}

\author{
Regine Margareta \\ English Literature \\ Universitas Negeri Surabaya \\ Surabaya, Indonesia \\ reginemargareta@yahoo.com
}

\begin{abstract}
This paper analyses the relationship among three fields; they are mental model, analogy, and local interpretation which are used as the basic principles to understand the problem in distinguishing people's responses toward verses in Quran. It uses the theories of Laird Johnson (1983) [1] and George Yule \& Gillian Brown (1983) [2]. The theories are used to show that the mental models should not be a way to create stereotype and how people comprehend something differently beyond their culture, whereas culture is associated with analogy. Thus, there are always various interpretations especially in interpreting Quran which Muslims believe that Quran should not be translated. Yet, on the other hand, it is not the fault of the readers when they interpret differently and it is also not the fault of the translators.
\end{abstract}

Keywords - mental model, analogy, local interpretation, Quran, Translation.

\section{INTRODUCTION}

Language is the most important aspect in humans' life because without language one person will not be able to communicate and share the feeling. People in the world who have religion may understand that what is happening in the humans' life is also controlled by the Almighty One, who is called God. Commonly God had sent His passengers to spread the ideology of peace in the entire world to perform what is good and avoid what is bad. Some of the passengers brought the holy books for example the Holy Bible (Injeel), Quran (AlQuran), Torah (Tawrat), etc. In this article, it concerns to Quran which was in a binding ruling in religious matters on Tuesday, 1 Safar $1433 \mathrm{H} /$ December, 27 th $^{\text {th }} 2011$ in Arrahmah.com. The matters are the law of translating Quran in fatwa number 833, chapter 4 which is about a question related to Quran translation:

Translating Quran or some verses into other languages to spread the right Islam proselytizing to non-Muslim countries, is this effort in syari'ah and religion wrong? Then the answer of translating Quran or some verses of It, to fully explain the meaning in Quran is impossible. That is the biggest reason why translating Quran or some verses of It literally is forbidden. The accident will result to the wrong interpretation that out of the actual meaning (p. 132).

This statement of forbidden Quran translation can be seen throughout the impact of the misunderstanding comments related to violent events related to Islam in social media. Facebook is also a social media in the world today that has been the greatest role in influencing the people image toward Islam. The world still has the memory of the tragedy of Paris Attack 11/13, which in that time there were a lot of people insulting Islam and also its Quran. In that time, there were so many translated Quran's verses that are wrongly used by people in the world, which were used by the facebook commentators to reveal their opinion toward Islam. This latest incident in Paris which commit massacre attack on November 13th, 2017 is believed that was provoked by an ISIS incognito refugees. One status from BBC News account in facebook was also drawing attention the commentators. This status which was posted due to the tragedy of Paris Attack 11/13 caused a hazard mocking to the verses of Quran from non-Muslim commentators and stated wrong description of what so-called jihadist.

The comments of those non-Muslim commentators, which were based on the English translation of Quran by Maulawi Sher 'Ali and Yusuf-Ali, may have inappropriate words to describe the Islamic actions and ideology. The evidence shows that the comments somehow were made by wrong interpretation plus hatred which had been planted on the commentator's mind. This kind of comments from the nonmuslim commentator leads to the wrong interpretation because the commentators have different background and culture from Maulawi Sher 'Ali and Yusuf-Ali. Since the commentators have different background and culture, somehow what they intend to reveal is formed through what has been embedded from the commentator's background and culture. This embedded concept in the commentators' mind may become their only way to percept something which has been a model in their mind.

The image of the world around us, which we carry in our head, is just a model. Nobody in his head imagines all the world, government, or country. He has only selected concepts, and relationship between them, and uses those to represent the real system. [3]

In this case, the commentators have established the model of something mentally. A statement which was proposed by [4] which says that mental model is a way of how a speaker or listener interprets discourse relates it to his/her experience 
which will be matched to the knowledge that has been stored before in the brain system. Furthermore, speakers and listeners tend to understand an information based on what the culture has been taught to them, then making an interpretation is out of logical form [5]. Unconsciously the mental models are related to the principles of 'local interpretation' and of 'analogy' where there is a boundary of people's brain of how they understand something. Moreover, perhaps some people do not have an ability to think further of what their memory has kept, therefore the other people are those who may think in details. This capability of thinking is related to local interpretation [6]. Meanwhile, the principle of analogy will provide a reasonable secure framework of interpretation for the hearer. However, conventions can be flouted and the expectations is dissaponting, either deliberately for a stylistic effect, or by accident or oversight.

So, this paper explains 1) how mental models influence the local interpretation which restrain some parts of meaning in the translations, as well as 2) considering the effect in analogy aspect to the translator/interpreter. The method of this paper uses the comparison of some verses of Quran translation from two different translators which contained some harass words influence to people's hatred. The purpose of this paper is to prove that Quran should not be interpreted because the wrong meaning leads to dangerous perception between non-Muslims and Muslims, also the different interpretations are not the fault of the interpreters since some people might have different background such as the different analogy and the mental models that are combined with the local interpretation which will border the wider interpretation.

\section{THEORIES}

\section{A. SOURCES}

It is more likely to be called as concepts from several sources as explained below:

\section{1) The concept of mental models}

'We' as the speaker of a language might differ from speaker of other languages. For example, Indonesian which the language root is so different from English, they may have difficulties in understanding the concept when the interaction with other people whose nation has the language like English root. In the other way, for example, a nation like Netherlands which has the same language root like English root, they do not get difficulties when they interact with people from country which the language root is the same like English root. Meanwhile, if those two different languages (Bahasa Indonesia and Dutch) meet at the same context (English context), the speaker may have different perception of other people concept of background. The Dutch people will interpret most likely similar to the English; the similarities were established from their similar language roots and culture. In relation to how people establish their mental model, it is also related to 'experience'. Experience has also an important role on how someone's way of thinking. This is how the mental is build, it is from the experience. The mental models are supposed not to cause stereotype knowledge but in real life the mind has been set to tie with the experience, so the mental will cause the brain to think what has already known or what is commonly known.
Once again, those mental models are psychological representations that have the same relational structure as what they represent. They have been invoked to explain many important aspects of human reasoning, including deduction, induction, problem solving, language understanding, and human-machine interaction [6].

\section{2) The concept of principle of local interpretation}

This principle instructs the hearer not to construct a context any larger than he needs to arrive at an interpretation [6]. Since the word 'local' has some meanings such as relating to or occurring in particular area, not general or widespread, particular limited district, restricted part, etc. These meanings emerge one perception that the interpretation should not go too further. This is assumed that the translator or interpreter has to limit the interpretation. If local interpretation is correct, then the world is more simple, if the grammar directly assigns a meaning to each surface expression [7] that supports the previous quotation, then the meaning should only be in the surface (narrow thought). That is why, the local interpretation should meet the surface expression.

\section{3) The concept of analogy}

The study of analogy reveals the relation with mental models as long as analogies can serve as mental models for understanding a new domain. For example, notices in electricity are often about electricity current which uses mental models based on an analogy of water flow or with crowds of moving entities. These analogical mental models can be misleading as well as helpful [4]. Analogy tells about the comparison of things which are considered to be similar in some ways. The example is mostly taken from the comparison of past experience to present experience. This is the reason why analogy is so related to mental models.

\section{B. CORPUS DESCRIPTION}

1) The trending topic at that moment in the news worldwide

a) Islam and its Quran are considered as the trending topic in the news worldwide for several weeks, they are associated to the one of the fastest growing religion in the world that also has so many controversies. This makes Quran as one of the object that should be revealed deeper by people.

b) Facebook status which posted the tragedy of Paris Attack 11/13. That status has the attachment to the video (http://bbc.in/10JoBoF) which shows the moment explosions were heard at the Stade de France stadium.

c) The comments of the non-Muslim commentators toward the status of video Paris Attack 11/13 contain negative words, although they were related to the verses in Quran; however the verses that were used by those commentators provide inaccurate translation.

\section{2) The interest}

There are so many selective people put interest in studying Quran to reveal the best truth for every verse. When there is a mental model (word), it is most likely to be related to other mental aspect such as mental health. The studies of interpreting Quran might be huge, however there has slightly been found (almost similar to mental model and analogy) that metaphor is the most common theory put to interpret Quran. 


\section{3) Bryne's statement}

If mental models can be used to presume what is wrong momentarily then people in nowadays era might help to show the big distinctions between exact periods [8]. Whether or not that actually human use the mental model as the aspect to interpret anything in their mind or they use other aspects. This is still questionable.

\section{METHOD}

This study uses qualitative method. The researcher screenshot comments as the pure data. Then commentators' identities are secretly investigated only based on the details that have been put by the commentators in the first time they joined Facebook (the courtesy of Facebook). The identity details depend on the commentators themselves whether they show all of the details, or some of the Facebook users usually hide some details that they do not want public to know, such as the year of birth, living location, etc. The risk of invalid identity details in this research is pretty slight since most of the commentators are considered to be an adult. The screenshot pictures which contain the comments (in paragraphs) will reveal the opinions of the commentators from around the world which are mostly taken from Americans. Then, from what they believe is true, it will be compared to the Quran translation from a translator whose background is from middle eastern country which the culture must be more or less similar to where the Quran was firstly revealed. However, the translators did not only live in one country and stuck, instead, they had lived in other countries which make their knowledge richer with culture, perspective, experience etc. This method is used to convince someone else's perspective which usually needs a number of mass that has the same opinion. Hence, the quality of the data is shown from the comments; and since those comments contain the evidence which they (non-Muslim commentators) are believed as the evidence which were taken from inaccuratetranslated Quran, it invites the advocated comments. For the second question, the data were taken from some biographies. The aim is to compare the biographies which can show the real truth of the authors.

\section{DISCUSSION}

\section{The status from Paris attack 11/13}

The status says that:

Paris Attacks: This video appears to show the moment explosions were heard at the Stade de France stadium. At least 40 people are feared dead multiple shooting and bomb attacks across the city.

This status was taken from facebook which was posted on November 14 th, 2015. It was posted three days after the tragedy Paris Attack on November 13th, 2015. This status had invited comments from people around the world and it provided some different point of view regarded the mental models of the commentators of that status.

The analysis below are divided into three parts, firstly it discusses how the mental model influence the local interpretation of the commentators comments toward the status, secondly it discusses how the analogy plays important role in the translators' mind regarding their mental model of Islam, and the last is about how the negative words influence the rebuilt-sentence of negative effects of the Paris Attack 11/13 Facebook status.

\section{A. Mental models influence the local interpretation}

Mental model was created in the brain that got the influences from people around the subject. People, as other subjects, carry information to share, to suggest, and to provoke other people to have the same understanding. Moreover, they are also taking their own effect to the subject to how they think and criticize.

\section{1) Data 1}

The first data is the comments from Dan Goor to the previous status. He moved in Fort Collins, Colorado on August $19^{\text {th }}, 1960$. Then moved again to Boston, Massachusetts on January $17^{\text {th }}, 1981$.

The possible model:

A lost young man is pointed to Mark Zuckerberg as what has been mentioned before as Dan Goor states 'Zuckerberg is typical little Jewish boy ...' the man has already been called little and word boy is another word for young man. The word lost shows as the act of supporting Islam. The word lost seems to despise Mr. Zuckerberg because of his action. What is lost? That is probably his mind as then supported with the phrase no regard to being rational. The word by being different means the lost man did something opposite.

\section{Possible reason:}

Dan Goor called Mark Zuckerberg as little Jewish and young man because the age gap. Take a look at Goor's moving to other state had already been done in 1960, so he was probably older when he moved so now in 2015 Goor is predicated to be older than years old.

\section{2) Data 2}

The second data is the comments from Michael Yon to the previous status. He was born in Winter Haven, Florida, United State, 1964. American author, independent writer, columnist, and photographer. Worked as army in early 1980s. Also worked as a writer in Iraq 2008 and in several countries like Israel, Afghanistan, Philippines, Brunei, Netherlands, Singapore, Cambodia, Laos, Vietnam, Thailand, Malaysia, Nepal, and the United States in 2009

\section{Possible model:}

Yon says 'people don't know the Bible from the Quran.' Yon considers that the word people is pointed to the Netherlanders as how Yon starts the comment. Then, make sure to watch the video with English subtitles means there are videos comparing the Holy Bible with the Quran and those videos have some versions which not all of them use English. The last, those quotations Yon mentions in his comments are believed to be the evidence of his first statement that the Holy Bible is from the Piece of Quran.

\section{Possible reason:}

When Yon says from Netherlands Yon probably is there in the country as what Yon's profile also mentions countries Yon 
has ever been visited. When he suggests make sure to watch the video with English subtitles proves that Yon uses English as the first language because Yon was born in the United States and he is known as American author.

\section{3) Data 3}

The third data is the comments from Lyall Chazen to the previous status From Marijamopole, Lithuania. Lives in Johannesburg, South Africa. Studied at Harvard Law School. Worked at Wrestling extreme club. Currently works at Tehran Times. Religion view is Roman Catholic.

\section{Possible model:}

They'd never be able to fool me as I know both the Bible and the Quran rather well the word they is pointed to Dutch because at the end of the paragraph he says 'and the Dutch...'. I know both the Bible and the Quran rather well...' Chazen must have read both Holy Bible and Quran before making comparison as well as supported with this statement '.. That is why I prefer the Holy Bible for it is clearly the unerring word of God while ...'.

\section{Possible reason:}

Chazen mentions at his profile on Facebook that Chazen is a Roman Catholic. This reveals that Chazen believes in the Holy Bible, the Holy Bible is used by Catholics and Christians. By the method Chazen explains his opinion is appropriate since Chazen does not judge the Dutch by the one side opinion but Chazen makes comparison of several prophets this is the method how Law students are prospected to solve an issue by different aspects as Chazen graduated from Harvard Law School.

From the analysis of possible model and possible reason, it can be resumed that mental model influences the local interpretation. People may get the data easily to know how people worldwide think about the Quran, is using Facebook searching engine type 'Koran' and shows the result. From the status people make then they are screenshotted to be the evidence. After that, people may check the user's profile page to know the interpretation. This is important to reveal the truth how their sentences get influenced by their identity boundary.

\section{B. Analogy's effect to a translator}

We also need to compare at least two sources of each biography as the aim to not get wrong data, then blend the two sources into two. To answer the question, it can use the comparison of the two works which will be more crystal clear what make the translation different. This is important to show that the analogy will always influence how people translate from one language to another language. It must be considered that translating a text is difficult because the translators have to understand to whom the text is read. But as readers too, they cannot blame translator as the varied interpretation because the analogy influences the way they spell their words.

\section{1) Data 4}

a) The mental model of Maulvi Sher Ali

Maulvi Sher Ali was born on November $24^{\text {th }}$ in Bhera, Sargodha, Pakistan, 1875 and died on November 13th, 1947 in Lahore Pakistan. He was brought up by a well off family. He is a son of Maulvi Nizam Ud Din and his mother died on March $7^{\text {th }}, 1907$. His religion view is Ahmadiyya. He is the founder of the Ahmadiyya movement in Islam also one of the earliest groundbreaking English translations of holy Quran. He began his journey to Europe in 1924. Be a profound scholar of Islamic sciences and the Arabic language. He also worked as an editor in some different places, a director publications at Qadian, as well as published an exposition and rebuttal of the book Yana Bi'ul Islam in his review of religion. He was buried in Bahishti Maqbara (the heavenly graveyard) at Rabwah. The sources of this biographic are from book page 148 explaining the company of the Promised Messiah, and then a group biography called the Ahmadiyya Movement in Islam 1987. Another resource is a newspaper called The Daily Alfazal published in 14 November 1947 after the death of Maulvi.

\section{b) The translation source's}

The translation Quran was published in Holland in 1955. The translated Quran was under the license of Islam International Publication Ltd, with four times correction. The corrections of the translation were made by Hadrat Mirza Masroor Ahmad, Hadrat Khalifatul Masih IV, and Hadrat Khalifatul Masih V.

The translation:

And kill them whenever you meet them and drive them out from where they have driven you out; for persecution is worse than killing. And fight them not in, and near the Sacred Mosque until they fight you therein. But if they fight you, then fight them; such is the requital for disbelievers (Al-Baqarah: 192).

So their Lord answered their prayers, saying, 'I will allow not the work of any worker from among of you, whether male or female, to be lost. You are from one another. Those, therefore, who have emigrated, and have been driven out from their homes, and have been persecuted in My cause, and have fought and been killed, I will surely remove from their evil and will cause them to enter Gardens through which streams flow-a reward from Allah, and with Allah is the best rewards", (Al-eImran: 196).

\section{c) The mental model influence analogy}

\section{Possible influence:}

Maulvi was brought up by well off family it means that he had a good education. His religion view was Ahmadiyya plus Maulvi was the founder of the Ahmadiyya movement in Islam. To be a founder Maulvi must have a great knowledge and had many good relations with people around or far away from him since Maulvi did not only stay in one country but also came to Europe. By the coming to Europe Maulvi must also have learned the distinctive culture because his hometown was in Pakistan. Maulvi also was profound in Arabic language which shows his talent in Arabic language is not questionable. The translation compared to Yusuf-Ali is quite different. The use of word persecution rather than oppression sounds way much better. And fight them not in or near the Sacred Mosque Maulvi gave more specific place. Then, such is the requital for disbelievers the word requital sounds sophisticated so the negative meaning is blurred. 
so their Lord answered their prayers, this sentence is complete, specific, and understandable that the Lord is God and $\mathrm{He}$ answered the prayers of those believers who prayed instead of answering a call or answering a mock (for instance). The repetition of persecution/persecuted be a good point that the readers see his firmness that was probably the reason why he became the founder of Ahmadiyya because he was firm with his words.

\section{d) The 8:12 Quran Translation}

Dan Goor mentioned the Quran's verse 8:12 and when the statement was matched to the two translation from two greatest Quran translator Yusuf-Ali and Maulvi Sher Ali the result is here:

"Remember thy Lord inspired the angels [with the message]: "I am with you: give firmness to the Believers: I will instil terror into the hearts of the Unbelievers: smite ye above their necks and smite all their finger-tips off them." - Yusuf Ali (8:12)

\section{Compared to}

"When thy Lord revealed to the angels, saying, 'I am with you; so give firmness to those who believe. I will cast terror into the heart of those who disbelieve. Smite, then, the upper parts of their necks, and smite off all finger-tips. ", - Maulvi (8:12)

From the Goor's comment:

"Terrorize and behead those who believe in scriptures other than the Koran."

From those two different translation, Goor's translation taken from somewhere out of those two great translator make the far misunderstood in Goor's perspective about too harass translation of Quran.

\section{2) Data 5}

a) The mental model of Abdullah Yusuf Ali

Abdullah Yusuf Ali was born on April $1^{\text {st }}, 1872$ in Bombay India. His religion view is Bohra Muslim. He was one of the India-English speaking Muslims; he also has great intellect and wide interest. His translation first was published in 1934 [9]. He married an Englishwoman in a church then got divorced as the result of unfaithfulness. He worked as British loyalty as well as a Civil Servant in British India) and he ever worked as Lahore ambassador. His opinion about Islam as personal salvation and said that he learnt nothing from the Qur'an itself. His career in translation wide-spread through UK and the US. His translation was funded by despotic Arab government seeking Islamic legitimacy from their own people and those important Muslim minorities living in Western countries (paraphrase). For Islam he built first mosque in Canada in 1938. He tragically died on December $10^{\text {th }}, 1953$ and buried in Brookwood cemetery in Woking Surrey UK [10]

\section{b) The translation source's}

The Quran translation was revised by the Presidency of Islamic Researches, IFTA, and Call and Guidance. The work of this translation (other than translating like editing and formatting was helped by a British man named William B. Brown). This translation is published in 1987 by the King Fahd Holy Quran Printing Complex.

\section{The translation:}

And slay them whenever ye catch them, and turn them out from where they have turned you out; for tumult and oppression are worse than slaughter; but fight them not at the Sacred Mosque, unless they [first] fight you there; but if they fight you, slay them. Such is reward of those who suppress faith (Al-Baqarah: 192).

And their Lord have accepted of them, and answered them: 'never will I suffer to be lost the work of any of you, be he male or female: Ye are members, one of another: Those who have left their homes, or been driven out there from, or suffered harm in My cause, or fought or been slain,- verily, I will blot out' (Al-e-Imran: 196).

\section{c) The mental model influence analogy}

\section{Possible influence:}

Yusuf-Ali was born 1872 means that Ali was three years older than Maulvi. In the previous passage mentioned that Ali was good in both Hindi - English language skill but does not mention the ability in Arabic language. He was introduced to have great intellect and interest that was why he could become a British Royalty and also an ambassador. Yet, he married an Englishman whom had different religion view and married in a church which commonly believed for fanatic people that stepping one foot to a church is a sin, this is so contrast of his own translation, but then the explanation he learnt nothing from the Quran itself (from the previous passage). Not to forget that also in the previous passage mentioned '... Arab government seeking Islamic legitimacy ... from their own people ... living in Western countries.' This purpose might not be the pure purpose of Islamic ideology to spread peace but to get advantage from the verses of the Quran to protect the Eastern people.

'And slay them ...' the word slay sounds so awful but the reason why Ali used this word because of the background of being a British Royal when battles and wars are the common issues to face as well as the words tumult and slaughter, which common in Army's daily life. But if they fight you, slay them this clause sounds unequal. How the fight is being equaled to slay. Like what has mentioned before about the purpose may explain the reason why the inequality appears here. The phrase suppress faith is like a persuasion.

And their Lord has accepted of them this clause does not show the completeness. Accepted what? And who is them? Because them can refer to the believers or disbelievers. 'Never will I suffer to be lost of ...' indeed the Lord (Allah) never suffered then Ali says '... and suffered harm in My cause ...' like God and Human feel the same suffer but it is believed to never compared God to His creatures. 'I will blot out' it feels like this sentence somehow inappropriate (sounds odd) because blot out can be replaced by more appropriate words such as conceal, hide, cover, or forget.

d) The Effect of Analogy toward the Local Interpretation of Facebook Comments

The analogy involves the culture, background, and environment. The same case applied in Dan Goor's comment when he mentioned the Quran verse 8:12 with a statement 
containing too harass words and too direct, compared to the two translation to the two biggest Quran translators from the past, the meaning and feeling that both translators created are different from Dan Goor's comment. The understanding of Dan Goor especially for the concept of Islamic Law might have misled. Taking a look at the two translators that are believed may sometimes make mistakes in a translation makes this issue obvious that even the great man can make mistake, and how about a person who only understand the second language translation that may never be introduced to Islam laws before.

\section{Negative words influences}

Some negative words may have influences which can be taken by looking at the comments where they put many inappropriate words since it becomes the target. This inappropriate words can be tested by putting them in a new sentence without using the same context as the comments in facebook status. From those new sentences, those inappropriate words still have negative meaning afterall.

The negative words in comments are terror, retard, evil, not, anti, hurt, mourn, allies, fuck, shit, jizzlam (Jihad Islam), ravenous, satanic, false, kill, demon, risk, death, wicked, against, devil.

Let us consider every negative word in each comment even in every sentence. To make it easy then take a look at those data 6,7 , and 8 , all of them are pointing at the same topic and mentioning the same name, that is Islam. The word Islam is used more than Muslim, Muhammad, and Allah. When those four words are not used, the negative words from the original comment will always give negative meaning in new sentences. The possible sentences could be:

- Some people hurt me and some people do not like me. They make a terror wherever I go. They think I am the evil one but I am not. They think I am the retarded one but I am not too. They are really anti-me.

- It is like a fuck shit when I come to his mourning day but people stare at me like I am their allies. I'm not like those jizzlam tho.

- It can be the fault of wicked people who lead this ravenous country where people kill people, and those believers worship demons. What kind of risk to take? Only me against them? A false ideology has been spread from the satanic mind to angelic brain, now people will never thought, the sufferance after the death.

From those new rebuild sentences out of the topic in screenshots show the same negative utterances. But by knowing the extended context the negative words show the hatred of the screenshots. The amount of the negative words in a comment can show the feeling of the commentators 'the more you talk, the more we know you' and hatred is one of the feeling beside happy, sad, excited, even determined.

\section{CONCLUSION}

This research can conclude that, the mental models have a relationship with analogy. Before mentioning analogy from the second question, the small scale of background check in mental model influences the way the commentators giving opinion. The experiences which they have been through reflect to how they criticize an issue. Second, the fault of misinterpretation is not only from the interpreter or translator but also to the different environment and era of time the interpreters live. Even before the moment when a human is born he has carried different mental intellectuality, mental storage, and mental health which then the mental creates a model which every model is different from other due to the experience and other aspects outside the body that influence him. Then, it is true that mental model influence the way people think and understand.

\section{REFERENCES}

[1] P. N. J. Laird, Mental models. Massachusetts: Harvard University Press, 1983.

[2] G. Yule and B. Gillian, Discourse Analysis. Cambridge: Cambridge University Press, 1983.

[3] J. W. Forrester, "Counterintuitive behavior of social System," Techonolgy Rev., vol. 73, no. 3, pp. 52-68, 1971.

[4] D. A. Gentener, A Comparison to cognitive scienc. Oxford: Blackwell, 1998.

[5] R. M. J. Byrne and J.-L. P. N., Deducation. Hove: Psycology Press, 1992.

[6] P. Thagard, The Brain and the Meaning of Life. Princeton: Princeton University Press, 2010.

[7] J. Holmes, An Introduction to Sociolinguistics. UK: Person Collage Div, 2013.

[8] R. M. J. Byrne, The Rational Imagination: How people Create Conterfactual Alternatives to Reality. Cambridge: MIT Press, 2005.

[9] M. A. Sherif, "Searching for Solace: A Biography of Abdullah Yusuf Ali - Translator of the Quran," Islamic Book, 1995. [Online]. Available: http://www.renaissance.com.pk/jabore96.html. [Accessed: 30-Nov1995].

[10] A. R. Koya, "Sad Ending of Abdullah Yousuf Ali - the Translator of Quran," Learning and Life, 2013. [Online]. Available: http://syedirfanhyder.blogspot.co.id/2013/08/sad-ending-of-abdullahyousuf-ali.html. 